\title{
PReS-FINAL-2240: Serum amyloid protein a concentration in CAPS patients treated with anti IL1B
}

\author{
S Pastore ${ }^{1 *}$, G Paloni ${ }^{1}$, M Gattorno ${ }^{2}$, A Taddio $^{3}$, L Lepore ${ }^{4}$, the CAPS Italian Register \\ From 20th Pediatric Rheumatology European Society (PReS) Congress \\ Ljubljana, Slovenia. 25-29 September 2013
}

\begin{abstract}
Introduction
Although all patients with chronic inflammatory conditions are at risk for developing type AA amyloidosis, the incidence varies widely between the different Autoinflammatory syndromes. The reported incidence is about $35 \%$ of patients with CAPS (cryopyrin-associated periodic syndrome) which comprises familial cold autoinflammatory syndrome (FCAS), Muckle-Wells syndrome and CINCA (chronic infantile neurological cutaneous, articular inflammatory syndrome). CAPS is associated with mutations in NLRP3/CIAS1 on chromosome $1 \mathrm{q} 44$, found only in about $50 \%$ of patients. Previous studies have demonstrated that IL- $1 \beta$ inhibitors are able to induce complete remission of clinical manifestations and suppression of markers of inflammation in the majority of patients.
\end{abstract}

\section{Objectives}

To evaluate Serum Amyloid A (SAA) level in CAPS patients treated with anti IL-1 $\beta$ therapy and to correlate its level with the response to the treatment and with the presence of the NLRP3 mutation.

\section{Methods}

We considered all patients of CAPS Italian Register affected by MWS or CINCA treated with IL- $1 \beta$ inhibitors (Anakinra or Canakinumab). According to Lachmann criteria a complete response to treatment was defined as a global assessment of no or minimal disease activity by a physician, an assessment of no or minimal rash, and a value for both serum CRP and SAA that was within the normal range $(<0.5 \mathrm{mg} / \mathrm{dL}$ for $\mathrm{CRP},<6.4 \mathrm{mg} / \mathrm{L}$ for SAA).

\footnotetext{
${ }^{1}$ University of Trieste, Trieste, Italy

() Biomed Central
}

Full list of author information is available at the end of the article
Partial response to IL-1 $\beta$ inhibitors was defined as a global assessment of no or minimal disease activity by a physician, and persistent elevated inflammatory markers (CRP, SAA). All patients underwent genetic analysis to identify NLRP3 mutations.

\section{Results}

26 patients $(15 \mathrm{M}, 11 \mathrm{~F})$ were considered, aged 2 to 52 years (median $16.5 \mathrm{ys}$ ). The mean duration of follow-up was 40 months. $18 / 26$ patients were in treatment with Canakinumab (5 patients ab initio and 13 after a period with Anakinra therapy) and 8/26 patients were still taking Anakinra. 10/26 patients showed clinical remission with normal lab tests, including SAA. 10/26 patients presented clinical remission and normal CRP, but elevated SAA, with median value of $12.8 \mathrm{mg} / \mathrm{L}$ (IQR 10.516.8). $3 / 26$ showed clinical remission but high values of SAA and CRP; $3 / 26$ patients presented clinical remission, normal SAA values, but high CRP values. So in this series only $10 / 26$ patients $(38 \%)$ affected by CAPS showed a complete response to IL- $1 \beta$ inhibitors. In 18/ 26 patients we detected a mutation of NLRP3 gene. Median value of SAA in the mutated patients was 6,7 (IQR 2,3-13,3), median value in no mutated patients was 6,6 (IQR 4,1-46,6).

\section{Conclusion}

In the previous studies complete response to anti-IL1 therapy fluctuates between $65 \%$ and $85 \%$. By contrast, in our experience anti-IL1 inhibitors induced complete remission in only $38 \%$ of the patients because SAA values remained high (double value respect normal range) in half patients with no correlation between SAA values and genetic background. We do not know the real risk of these patients of developing amyloidosis, but
C 2013 Pastore et al.; licensee BioMed Central Ltd. This is an Open Access article distributed under the terms of the Creative Commons Attribution License (http://creativecommons.org/licenses/by/2.0), which permits unrestricted use, distribution, and reproduction in any medium, provided the original work is properly cited. The Creative Commons Public Domain Dedication waiver (http:// creativecommons.org/publicdomain/zero/1.0/) applies to the data made available in this article, unless otherwise stated. 
we think that these patients need a constant long term follow up.

\section{Disclosure of interest}

None declared.

\section{Authors' details}

${ }^{1}$ University of Trieste, Trieste, Italy. ${ }^{2}$ UO Pediatria II, G. Gaslini Institute, Genoa, Italy. ${ }^{3}$ University of Trieste, Institute for Maternal and Child Health - IRCCS

"Burlo Garofolo, Italy. ${ }^{4}$ Institute for Maternal and Child Health - IRCCS "Burlo

Garofolo", Trieste, Italy.

Published: 5 December 2013

doi:10.1186/1546-0096-11-S2-P230

Cite this article as: Pastore et al:: PReS-FINAL-2240: Serum amyloid

protein a concentration in CAPS patients treated with anti IL1B. Pediatric

Rheumatology 2013 11(Suppl 2):P230.

Submit your next manuscript to BioMed Central and take full advantage of:

- Convenient online submission

- Thorough peer review

- No space constraints or color figure charges

- Immediate publication on acceptance

- Inclusion in PubMed, CAS, Scopus and Google Scholar

- Research which is freely available for redistribution

Submit your manuscript at www.biomedcentral.com/submit
Ciomed Central 